ISSN 0258-7122

Bangladesh J. Agril. Res. 38(3): 473-480, September 2013

\title{
EFFECT OF RATE OF ARBUSCULAR MYCORRHIZA INOCULUM ON TOMATO (Solanum lycopersicum) SEEDLINGS
}

\author{
M. A. H. BHUIYAN ${ }^{1}$
}

\begin{abstract}
An experiment on the effect of rate of Arbuscular mycorrhiza (AM) inoculum on tomato seedlings was conducted at Bangladesh Agricultural Research Institute, Joydebpur, Gazipur, Bangladesh for two consecutive years. Seven rates of AM inoculum viz., $0,0.5,1.0,1.5,2.0,2.5$, and $3.0 \mathrm{~kg} / \mathrm{m}^{2}$ were tested. Cowdung was used at a rate of $5 \mathrm{~kg} / \mathrm{m}^{2}$. Seeds were sown in $10 \mathrm{~cm}$ apart lines on 13 November 2007 and 11 November 2008, and the seedlings were thinned out to about $3 \mathrm{~cm}$ from seedling to seedling within a week of germination. Roma VF was used as a variety of tomato. Biomass yield, root colonization, spore number, and nutrient uptake by tomato seedlings increased remarkably with the rates of AM inoculum. The biomass yield followed a quadratic trend with the increase of AM inoculum rate from 0 to $2.0 \mathrm{~kg} / \mathrm{m}^{2}$ in $2007-08$ and 0 to $1.5 \mathrm{~kg} / \mathrm{m}^{2}$ in $2008-09$.
\end{abstract}

Keywords: Tomato seedlings, Arbuscular mycorrhiza, nutrient uptake.

\section{Introduction}

Arbuscular mycorrhiza form symbiotic association with most of the terrestrial plants species (Azizah, 1999; Richardson et al., 2000; Sramek et al., 2000). About $90 \%$ of all plant species including most agricultural, horticultural, and tree crops form mycorrhizae (Read et al., 1992). More than 6,000 fungal species are capable of establishing mycorrhizas with about 240,000 plant species (Bonfante and Perotto, 1995). Arbuscular mycorrhiza is the most common type occurring in about $80 \%$ of the plant species. They are the most suitable type for development programmes based on low-input agriculture (Bethelenfalvay and Linderman, 1992). Arbuscular mycorrhiza occurs in about $83 \%$ of dicotyledonous and $79 \%$ of monocotyledonous plants (Trappe, 1987). All gymnosperms are reported to be mycorrhizal (Newman and Reddell, 1987). Arbuscular mycorrhiza fungal associations have been observed in 1000 genera of plants representing 200 families.

Arbuscular mycorrhizal fungi benefit plant in a number of ways to increase plant productivity and to conserve soil to sustain future production. The major benefits of AM association are (i) increase uptake of immobile nutrients particularly phosphorus and micronutrients (Azizah and Martin, 1992; Douds and Millner, 1999); (ii) higher production of growth regulating substances

${ }^{1}$ Principal Scientific Officer, Soil Science Division, Bangladesh Agricultural Research Institute (BARI), Gazipur-1701, Bangladesh. 
(Danneberg et al., 1992); (iii) increase rate of photosynthesis (Masri, 1997; Syvertsen and Graham, 1999); (iv) increase uptake of water and osmotic adjustment under drought stress (Auge et al., 1986; Masri, 1997); (v) enhancement of symbiotic $\mathrm{N}_{2}$-fixation through increase $\mathrm{P}$ supply (Kucey and Paul, 1982); (vi) resistance to pests and diseases (Bethlenfalvay and Linderman, 1992; Ho, 1998); (vii) helps in the formation of soil aggregation and aggregate stability (Azizah and Idris, 1996); (viii) improves soil-plant-water relation (Kothari et al., 1990; Masri, 1997; Jastrow et al., 1998), and (ix) confers protection against toxic-metals (Azizah et al., 1989; Bonifacio et al., 1999). Mycorrhizal association also helps in uptake of other macro-and micronutrients. A conservative estimate suggests that the external hyphae of AM can deliver up to $25 \%$ of $\mathrm{N}, 80 \%$ of $\mathrm{P}, 10 \%$ of $\mathrm{K}, 25 \% \mathrm{Zn}$ and $60 \%$ of plant $\mathrm{Cu}$ (Marschner and Dell, 1994).

However, the benefits from a mycorrhizal association depend largely on establishment of an effective association between the plant roots and AM fungus. Establishment of AM association depends on density and number of AM propagules (spore, mycelium, infected root pieces etc.) in the growing media. The present investigation was therefore undertaken to observe the effect of different rates of AM inoculum on the performance of tomato seedlings.

\section{Materials and Method}

An experiment on tomato seedlings was conducted in the seedbeds $(3 \mathrm{~m} \times 1 \mathrm{~m})$ of Soil Science Division, Bangladesh Agricultural Research Institute (BARI), Joydebpur, Gazipur, Bangladesh during the rabi season of 2007-08 and 2008-09. Silted soil from the bank of Turag river at Kodda, Gazipur was used in the seedbed. The soil of the seedbed was sandy clay loam in texture having $\mathrm{pH} 7.4$, organic matter $0.53 \%$, total N $0.03 \%$, available P $11.0 \mu \mathrm{g} / \mathrm{g}$, available S 10.0 $\mu \mathrm{g} / \mathrm{g}$, exchangeable $\mathrm{K} 0.15 \mathrm{meq} / 100 \mathrm{~g}$, exchangeable Ca $3.80 \mathrm{meq} / 100 \mathrm{~g}$, exchangeable Mg $1.10 \mathrm{meq} / 100 \mathrm{~g}$, available Zn $2.50 \mu \mathrm{g} / \mathrm{g}$, available B $0.14 \mu \mathrm{g} / \mathrm{g}$, available $\mathrm{Cu} 2.10 \mu \mathrm{g} / \mathrm{g}$, available Fe $35 \mu \mathrm{g} / \mathrm{g}$, and available $\mathrm{Mn} 11 \mu \mathrm{g} / \mathrm{g}$. The soil was slightly alkaline in reaction. Organic matter, major nutrients, and zinc and copper contents of the soil were low, while iron and manganese levels were quite high. The soil contained 10 AM spores of indigenous mixed AM fungal species and the experiment was conducted under non-sterilized soil condition.

The experiment was laid out in randomized complete block (RCB) design with four replications. Seven rates of mixed AM inoculum viz., 0, 0.5, 1.0, 1.5, $2.0,2.5$, and $3.0 \mathrm{~kg} / \mathrm{m}^{2}$ were studied on tomato seedlings. The seed bed was divided into seven separate unit plot by inserting thick polyethylene sheet upto 25 $\mathrm{cm}$ depth of soil to check the contamination of AM among the plots. Cowdung was used at the rate of $5 \mathrm{~kg} / \mathrm{m}^{2}$. No other fertilizers were used. Seeds were sown in $10 \mathrm{~cm}$ apart lines on 13 November 2007 and 11 November 2008. Soil based 
AM inoculum was used in the seed furrows of about $3 \mathrm{~cm}$ depth. A soil layer of about $1 \mathrm{~cm}$ thickness was spread on the inoculum layer on which the seeds were sown. Roma VF was used as the variety of tomato. The seedlings were thinned down to about $3 \mathrm{~cm}$ from seedling to seedling within a week of germination. Watering, weeding, and other intercultural operation were done as and when necessary. The seedlings were harvested on 11 December 2007 and 17 December 2008. Data on biomass yield and yield components were recorded. Plant samples were oven dried at $70^{\circ} \mathrm{C}$ until constant weight. Chemical analyses of the samples were done and nutrient uptake by the seedlings was calculated. Data were analyzed using the statistical package IRRISTAT.

\section{Results and Discussion}

\section{Performance of tomato seedlings}

Biomass yield of tomato seedlings has been presented in Fig. 1. The biomass yield of the seedlings followed quadratic trend with the increase of AM inoculum rate. The response curve shows that the highest biomass $(435 \mathrm{mg}$ per seedling in 2007-08 and $399 \mathrm{mg}$ per seedling in 2008-09) of tomato seedlings was produced with the AM inoculum rate of about $2.0 \mathrm{~kg}$ per $\mathrm{m}^{2}$ in $2007-08$ and $1.5 \mathrm{~kg}$ per m in 2008-09. Similar trend in shoot and root weight of the seedlings was also observed with the increase of AM inoculum rate (Table 1). Better performance of inoculated seedlings might be due to beneficial effects of AM fungi. There are many evidence of better performance of AM inoculated seedlings compared to those without inoculation (Masri, 1997; Satter, 2000 and Satter and Khanam, 2002). Root colonization and spore number in tomato seedlings was found to increase with the increase of inoculum rate up to 2.0 to $2.5 \mathrm{~kg}$ per $\mathrm{m}^{2}$. There was also some root colonization in the control seedlings with native AM fungi. This might be due to survival of some native AM fungi in soil.

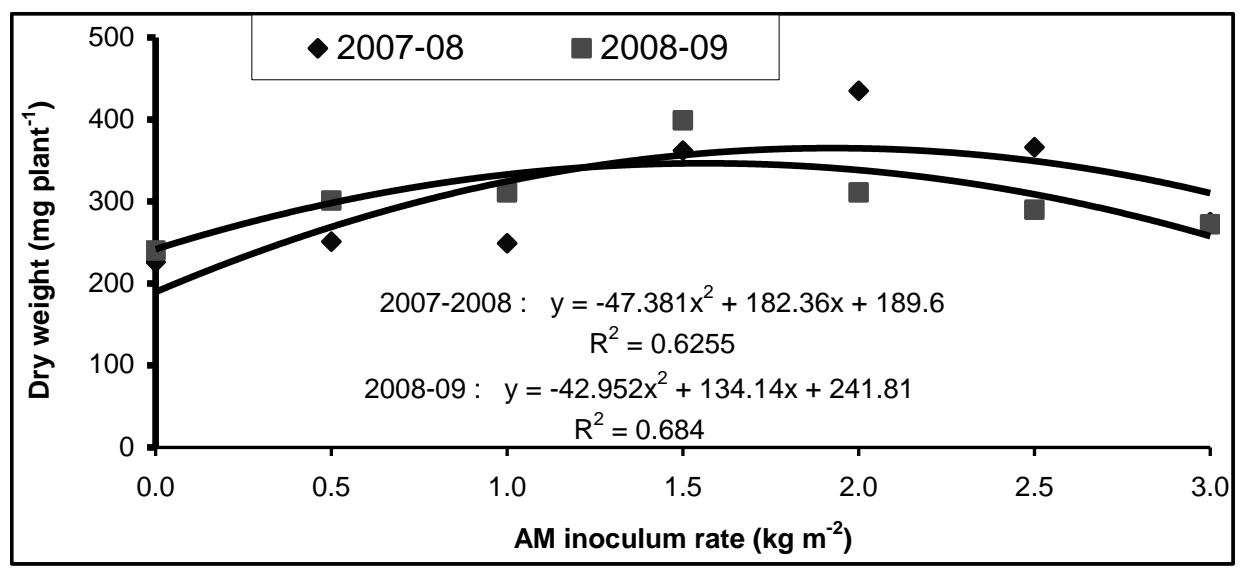

Fig. 1. Effect of AM inoculum rate on dry weight of tomato seedlings. 
Table 1. Effect of rate of AM inoculum on root weight, shoot weight, root colonization and spore numbers of tomato seedlings in seedbed in 2007-08 and 2008-09.

\begin{tabular}{|c|c|c|c|c|c|c|c|c|}
\hline \multirow[b]{2}{*}{$\begin{array}{l}\text { Inoculum } \\
\text { rate } \\
\left(\mathrm{kg} / \mathrm{m}^{2}\right)\end{array}$} & \multicolumn{4}{|c|}{ 2007-08 } & \multicolumn{4}{|c|}{ 2008-09 } \\
\hline & $\begin{array}{c}\text { Shoot wt } \\
(\mathrm{mg} / \\
\text { seedling) }\end{array}$ & $\begin{array}{c}\text { Root wet } \\
\text { (mg/ } \\
\text { seedling) }\end{array}$ & $\begin{array}{c}\text { Root } \\
\text { coloniza } \\
- \text { tion }(\%)\end{array}$ & $\begin{array}{c}\text { Spore } \\
\text { no. }(100 / \\
\text { g soil })\end{array}$ & $\begin{array}{c}\text { Shoot wt } \\
(\mathrm{mg} / \\
\text { seedling) }\end{array}$ & $\begin{array}{c}\text { Root wt } \\
(\mathrm{mg} / \\
\text { seedling) }\end{array}$ & $\begin{array}{c}\text { Root } \\
\text { coloniza } \\
\text {-tion }(\%)\end{array}$ & $\begin{array}{c}\text { Spore } \\
\text { no. }(100 / \\
\text { g soil) }\end{array}$ \\
\hline 0 & $204 b$ & $22 c$ & $20.0 \mathrm{c}$ & $10.0 \mathrm{~d}$ & $216 b$ & $24 c$ & $25.0 \mathrm{~d}$ & $20.0 \mathrm{~d}$ \\
\hline 0.5 & $225 b$ & $26 \mathrm{c}$ & $25.0 \mathrm{c}$ & $15.0 \mathrm{~cd}$ & $268 b$ & $33 b c$ & $30.0 \mathrm{~cd}$ & $25.0 \mathrm{~d}$ \\
\hline 1.0 & $214 b$ & $35 \mathrm{c}$ & $30.0 \mathrm{c}$ & $20.0 \mathrm{~cd}$ & $272 b$ & $39 \mathrm{ab}$ & $35.0 \mathrm{c}$ & $40.0 \mathrm{c}$ \\
\hline 1.5 & $304 a$ & $58 b$ & $40.0 \mathrm{~b}$ & $25.0 \mathrm{bc}$ & $355 a$ & $44 a$ & $50.0 \mathrm{~b}$ & $50.0 \mathrm{~b}$ \\
\hline 2.0 & $357 \mathrm{a}$ & $78 a$ & $60.0 \mathrm{a}$ & $35.0 \mathrm{~b}$ & $270 \mathrm{~b}$ & $41 \mathrm{ab}$ & $55.0 \mathrm{ab}$ & $60.0 \mathrm{a}$ \\
\hline 2.5 & $329 a$ & $37 \mathrm{c}$ & $50.0 \mathrm{ab}$ & $55.0 \mathrm{a}$ & $249 b$ & $41 \mathrm{ab}$ & $60.0 \mathrm{a}$ & $50.0 \mathrm{~b}$ \\
\hline 3.0 & $236 b$ & $39 c$ & $40.0 \mathrm{~b}$ & $50.0 \mathrm{a}$ & $235 b$ & $37 \mathrm{ab}$ & $55.0 \mathrm{ab}$ & $50.0 \mathrm{~b}$ \\
\hline F Test & $* *$ & $* *$ & $* *$ & $* *$ & $*$ & $*$ & $* *$ & $* *$ \\
\hline $\mathrm{CV}(\%)$ & 10.4 & 18.3 & 14.7 & 16.3 & 20.3 & 18.7 & 14.2 & 15.4 \\
\hline
\end{tabular}

Means followed by common letter(s) are not significantly different at $5 \%$ level by DMRT.

\section{Nutrient uptake by tomato seedlings}

Nutrient uptake by tomato seedlings has been presented in Tables 2 and 3 . Uptake of all the major and minor nutrients increased significantly with AM inoculation which might have enhanced the inoculated seedlings to produce more biomass and better growth compared to the non-inoculated seedlings. Uptake of nutrients by non-inoculated seedlings were $7.47 \mathrm{mg} \mathrm{N}, 1.89 \mathrm{mg} \mathrm{P}, 7.13 \mathrm{mg} \mathrm{K}$, $5.48 \mathrm{mg} \mathrm{Ca}, 1.29 \mathrm{mg} \mathrm{Mg}, 0.99 \mathrm{mg} \mathrm{S}, 94 \mu \mathrm{g} \mathrm{B}, 47.7 \mu \mathrm{g} \mathrm{Cu}, 932 \mu \mathrm{g} \mathrm{Fe}, 161 \mu \mathrm{g}$ $\mathrm{Mn}$, and $84.6 \mu \mathrm{g} \mathrm{Zn}$ per seedling in 2007-08, and $7.67 \mathrm{mg} \mathrm{N}, 0.81 \mathrm{mg} \mathrm{P}, 3.44 \mathrm{mg}$ $\mathrm{K}, 3.26 \mathrm{mg} \mathrm{Ca}, 1.67 \mathrm{mg} \mathrm{Mg}, 0.44 \mathrm{mg} \mathrm{S}, 101 \mu \mathrm{g} \mathrm{B}, 41.8 \mu \mathrm{g} \mathrm{Cu}, 1450 \mu \mathrm{g} \mathrm{Fe}$, $271 \mu \mathrm{g} \mathrm{Mn}$, and $166 \mu \mathrm{g} \mathrm{Zn}$ per seedling in 2008-09, respectively (Table 2 and 3). While uptake of nutrients by inoculated seedlings ranged from 7.69 to $12.99 \mathrm{mg}$ $\mathrm{N}, 2.10$ to $3.71 \mathrm{mg} \mathrm{P}, 8.55$ to $14.96 \mathrm{mg} \mathrm{K}, 6.21$ to $11.36 \mathrm{mg} \mathrm{Ca}, 1.27$ to $2.48 \mathrm{mg}$ $\mathrm{Mg}$, and 1.78 to $3.06 \mathrm{mg} \mathrm{S}, 99$ to $175 \mu \mathrm{g} \mathrm{B}, 53.7$ to $89.3 \mu \mathrm{g} \mathrm{Cu}, 827$ to $1734 \mu \mathrm{g}$ $\mathrm{Fe}, 211$ to $324 \mu \mathrm{g} \mathrm{Mn}$ and 90.8 to $156.9 \mu \mathrm{g} \mathrm{Zn}$ per seedling in 2007-08 and 8.69 to $13.29 \mathrm{mg} \mathrm{N}, 1.09$ to $1.43 \mathrm{mg} \mathrm{P}, 4.64$ to $6.09 \mathrm{mg} \mathrm{K}, 4.39$ to $6.53 \mathrm{mg} \mathrm{Ca}, 2.34$ to $3.23 \mathrm{mg} \mathrm{Mg}$ and 0.58 to $0.73 \mathrm{mg} \mathrm{S}, 133$ to $214 \mu \mathrm{g} \mathrm{B}, 57.0$ to $79.8 \mu \mathrm{g} \mathrm{Cu}, 1753$ to $2747 \mu \mathrm{g} \mathrm{Fe}, 331$ to $463 \mu \mathrm{g} \mathrm{Mn}$, and 183 to $275 \mu \mathrm{g}$ Zn per seedling in 2008-09. Trend in uptake of nutrients in most of the cases with increasing the rate of AM inoculum up to $2.0 \mathrm{~kg}$ per $\mathrm{m}^{2}$ in $2007-08$ and $1.5 \mathrm{~kg}$ per $\mathrm{m}^{2}$ in $2008-09$ was also 
observed. The external hyphae can extend up to several centimeters beyond the mycorrhizal root surface and can increase root surface area and the absorption zone for exploration of greater soil volume for nutrient and moisture uptake (Johansen et al., 1993). Mycorrhizal fungal hyphae were found to intercept labeled P placed $27 \mathrm{~cm}$ apart from a mycorrhizal root, whereas it remained unavailable to non-mycorrhizal roots (Hattingh et al., 1973). The radius of the depletion zone for $\mathrm{P}$ around mycorrhizal onion roots was found twice that for non-mycorrhizal roots (Owusu-Bennoah and Wild, 1980). The rate of nutrient uptake by mycorrhizal roots is also faster than that by non-mycorrhizal roots (Son and Smith, 1988).

Table 2. Effects of rate of AM inoculum on uptake of major nutrients by tomato seedlings during rabi seasons of 2007-08 and 2008-09.

\begin{tabular}{|c|c|c|c|c|c|c|}
\hline \multirow{2}{*}{$\begin{array}{l}\text { AM Inoculum } \\
\text { rate }\left(\mathrm{kg} / \mathrm{m}^{2}\right)\end{array}$} & \multicolumn{6}{|c|}{ Uptake of macronutrients (mg/seedling) } \\
\hline & $\mathrm{N}$ & $P$ & $\mathrm{~K}$ & $\mathrm{Ca}$ & $\mathrm{Mg}$ & $\mathrm{S}$ \\
\hline \multicolumn{7}{|l|}{ 2007-08 } \\
\hline 0 & $7.47 \mathrm{~b}$ & $1.89 \mathrm{~d}$ & $7.13 \mathrm{~d}$ & $5.48 \mathrm{c}$ & $1.29 \mathrm{~b}$ & $0.99 \mathrm{e}$ \\
\hline 0.5 & $7.93 b$ & $2.10 \mathrm{c}$ & $8.55 \mathrm{~cd}$ & $6.42 \mathrm{c}$ & $1.43 b$ & $1.78 \mathrm{~d}$ \\
\hline 1.0 & $8.35 b$ & $2.21 \mathrm{c}$ & $9.57 \mathrm{~cd}$ & $6.21 \mathrm{c}$ & $1.27 \mathrm{~b}$ & $2.11 \mathrm{~cd}$ \\
\hline 1.5 & $12.99 \mathrm{a}$ & $3.55 \mathrm{a}$ & $12.34 b$ & $9.45 b$ & $2.48 \mathrm{a}$ & $2.77 \mathrm{ab}$ \\
\hline 2.0 & $12.80 \mathrm{a}$ & $3.71 \mathrm{a}$ & $14.80 \mathrm{a}$ & $11.36 \mathrm{a}$ & $2.27 \mathrm{a}$ & $3.06 \mathrm{a}$ \\
\hline 2.5 & $12.26 \mathrm{a}$ & $3.35 \mathrm{ab}$ & $14.96 \mathrm{a}$ & $9.12 b$ & $2.15 \mathrm{a}$ & $2.52 b c$ \\
\hline 3.0 & $7.69 \mathrm{~b}$ & $2.31 \mathrm{c}$ & $10.54 b c$ & $6.59 \mathrm{c}$ & $1.60 \mathrm{~b}$ & $1.90 \mathrm{~d}$ \\
\hline F test & $* *$ & $* *$ & $* *$ & $* *$ & $* *$ & $* *$ \\
\hline $\mathrm{CV}(\%)$ & 9.7 & 9.5 & 8.7 & 9.2 & 9.7 & 8.9 \\
\hline \multicolumn{7}{|l|}{ 2008-09 } \\
\hline 0 & $7.67 b$ & $0.81 b$ & $3.44 b$ & $3.26 \mathrm{c}$ & $1.67 \mathrm{c}$ & $0.44 b$ \\
\hline 0.5 & $10.72 \mathrm{ab}$ & $1.09 \mathrm{ab}$ & $5.04 \mathrm{a}$ & $5.03 \mathrm{ab}$ & $2.42 b c$ & $0.62 \mathrm{ab}$ \\
\hline 1.0 & $10.00 \mathrm{~b}$ & $1.43 \mathrm{a}$ & 4.66ab & $5.35 \mathrm{ab}$ & $2.70 \mathrm{ab}$ & $0.58 \mathrm{ab}$ \\
\hline 1.5 & $13.29 \mathrm{a}$ & $1.40 \mathrm{a}$ & $6.09 a$ & $6.53 \mathrm{a}$ & $3.23 \mathrm{a}$ & $0.72 \mathrm{a}$ \\
\hline 2.0 & $10.62 \mathrm{ab}$ & $1.15 \mathrm{ab}$ & $5.29 a$ & $4.69 b c$ & $2.34 b c$ & $0.73 a$ \\
\hline 2.5 & $9.50 \mathrm{~b}$ & $1.17 \mathrm{ab}$ & $4.64 \mathrm{ab}$ & $4.39 b c$ & $2.47 \mathrm{abc}$ & $0.71 \mathrm{a}$ \\
\hline 3.0 & $8.79 b$ & $1.10 \mathrm{ab}$ & 4.79ab & $4.52 b c$ & $2.41 b c$ & $0.68 \mathrm{a}$ \\
\hline F test & $*$ & $*$ & $*$ & $* *$ & $*$ & $*$ \\
\hline $\mathrm{CV}(\%)$ & 19.1 & 19.7 & 18.8 & 20.5 & 20.0 & 19.3 \\
\hline
\end{tabular}

Means followed by common letter(s) are not significantly different at $5 \%$ level by DMRT. 
Table 3. Effects of rate of $A M$ inoculum on uptake of minor nutrients by tomato seedlings during rabi seasons of 2007-08 and 2008-09.

\begin{tabular}{|c|c|c|c|c|c|}
\hline \multirow{2}{*}{$\begin{array}{c}\mathrm{AM} \\
\text { Inoculum rate }\left(\mathrm{kg} / \mathrm{m}^{2}\right)\end{array}$} & \multicolumn{5}{|c|}{ Uptake of micronutrients ( $\mu \mathrm{g} /$ seedling) } \\
\hline & $\mathrm{B}$ & $\mathrm{Cu}$ & $\mathrm{Fe}$ & $\mathrm{Mn}$ & $\mathrm{Zn}$ \\
\hline \multicolumn{6}{|l|}{ 2007-08 } \\
\hline 0 & $94 b$ & $47.7 \mathrm{~b}$ & $932 d$ & $161 \mathrm{c}$ & $84.6 c$ \\
\hline 0.5 & $105 b$ & $53.7 \mathrm{~b}$ & $1023 \mathrm{~cd}$ & $211 b c$ & $95.3 \mathrm{c}$ \\
\hline 1.0 & $102 b$ & $53.2 b$ & $827 d$ & $231 b$ & $89.4 \mathrm{c}$ \\
\hline 1.5 & $150 \mathrm{a}$ & $79.3 \mathrm{a}$ & $1209 c$ & $324 a$ & $122.3 b$ \\
\hline 2.0 & $175 \mathrm{a}$ & $89.3 \mathrm{a}$ & $1734 \mathrm{a}$ & $314 \mathrm{a}$ & $156.9 \mathrm{a}$ \\
\hline 2.5 & $157 \mathrm{a}$ & $75.9 a$ & $1470 \mathrm{~b}$ & $314 a$ & $138.6 \mathrm{ab}$ \\
\hline 3.0 & $99 \mathrm{~b}$ & $60.5 \mathrm{~b}$ & $965 \mathrm{~cd}$ & $234 b$ & $90.8 \mathrm{c}$ \\
\hline F test & $* *$ & $* *$ & $* *$ & $* *$ & $* *$ \\
\hline $\mathrm{CV}(\%)$ & 9.2 & 9.2 & 8.7 & 9.1 & 8.8 \\
\hline \multicolumn{6}{|l|}{ 2008-09 } \\
\hline 0 & $101 \mathrm{c}$ & $41.8 \mathrm{c}$ & $1450 \mathrm{c}$ & $271 c$ & $166 \mathrm{~b}$ \\
\hline 0.5 & $133 b c$ & $57.0 \mathrm{bc}$ & $1814 b c$ & $378 \mathrm{abc}$ & $213 \mathrm{ab}$ \\
\hline 1.0 & $140 \mathrm{bc}$ & $63.7 \mathrm{ab}$ & $2154 \mathrm{ab}$ & $367 \mathrm{abc}$ & $224 a b$ \\
\hline 1.5 & $214 \mathrm{a}$ & $79.8 \mathrm{a}$ & $2747 \mathrm{a}$ & $463 a$ & $275 a$ \\
\hline 2.0 & $164 \mathrm{ab}$ & $66.5 \mathrm{ab}$ & $1856 b c$ & $397 \mathrm{ab}$ & $221 \mathrm{ab}$ \\
\hline 2.5 & $167 \mathrm{ab}$ & $62.2 \mathrm{ab}$ & $1921 b c$ & $352 \mathrm{abc}$ & $209 b$ \\
\hline 3.0 & $143 b c$ & $63.7 \mathrm{ab}$ & $1753 \mathrm{bc}$ & $331 b c$ & $183 b$ \\
\hline F test & $* *$ & $*$ & $* *$ & $*$ & $*$ \\
\hline $\mathrm{CV}(\%)$ & 21.2 & 19.2 & 20.7 & 19.2 & 18.8 \\
\hline
\end{tabular}

Means followed by common letter(s) are not significantly different at $5 \%$ level by DMRT.

From the results, it is evident that the biomass yield, root colonization, spore number in rhizosphere soil and nutrient uptake by tomato seedlings increased significantly with the use of AM inoculum. Biomass yield of tomato seedlings followed quadratic trend with the increase of AM inoculum rate.

\section{References}

Auge, R. M., K. A. Schekel and R. L. Wample. 1986. Osmotic adjustment in leaves of VA mycorrhizal and nonmycorrhizal rose plants in response to drought stress. Plant Physiol. 82: 765-770.

Azizah, H. and Z. A. Idris. 1996. Microbes: how they can do wonders to soil fertility. Malaysian Technol. Bull. 4: 92-94. 
Azizah, H. and K. Martin. 1992. The vesicular-arbuscular mycorrhiza and its effects on growth of vegetatively propagated Theobroma cacao L. Plant Soil 144: 227-233.

Azizah, H., S. Puziah and Y. K. Chan. 1989. Growth response of selected fruit seedlings to VA inoculation in acid-sulphate soils. In: Proc. National Seminar on Soil Management for Food and Fruit Crop Production. Mar. 28-29, 1989. Kuala Lumpur, Malaysia Pp. 111-118.

Azizah, H. 1999. The endomycorrhiza: a futile investment? Syarahan Inaugural. Oct. 23, 1999. Dewan Fakulti Pertanian. Universiti Putra Malaysia, Serdang, Malaysia.

Bethelenfalvay, G. J. and R. G. Linderman. 1992. Mycorrhizae in Sustainable Agriculture. American Soc. Agron. Special Publication No. 54. Medison, USA.

Bonfante, P. and S. Perotto. 1995. Strategy of arbuscular mycorrhizal fungi when infecting host plants. New Phytol. 130: 3-21.

Bonifacio, E., G. Nicolotti, E. Zanini and G. P. Cellerino. 1999. Heavy metal uptake by mycorrhizae of beech in contaminated and uncontaminated soils. Fresenius Environ. Bull. 7: 408-413.

Danneberg, G., C. Latus, W. Zimmer, B. Hundes-Hagen, H. Schneider-Poetsch and H. Bothe. 1992. Influence of vesicular-arbuscular mycorrhiza on phytohormone balances in maize (Zea mays L.). J. Plant Physiol. 141: 33-39.

Douds, D. D. and P. Millner. 1999. Biodiversity of arbuscular mycorrhizal fungi in agroecosystems. Agric. Ecosyst. Environ. 74: 77-93.

Hattingh, M. J. L. E. Gray and J. W. Gerdemann. 1973. Uptake and translocation of ${ }^{32} \mathrm{P}$ labeled phosphate to onion roots by endomycorrhizal fungi. Soil Sci. 116: 383-387.

Ho, C. T. 1998. Safe and efficient management systems for plantation pests and diseases. The Planter 74: 369-385.

Jastrow, J. D., R. M. Miller and J. Lussenhop. 1998. Contributions of interacting biological mechanisms to soil aggregate stabilization in restored prairie. Soil Biol. Biochem. 30: 905-916.

Johansen, A., I. Jacobsen and E. S. Jensen. 1993. External hyphae of vesicular-arbuscular mycorrhizal fungi associated with Trifolium subterraneum L. 3. hyphal transport of ${ }^{32} \mathrm{P}$ and ${ }^{15} \mathrm{~N}$. New Phytol. 124: 61-68.

Kothari, S. K., H. Marschner and E. George. 1990. Effect of VA mycorrhizal fungi and rhizosphere microorganisms on root and shoot morphology, growth and water relations of maize. New Phytol. 116: 303-311.

Kucey, R. M. N. and E. A. Paul. 1982. Carbon flow, photosynthesis and $\mathrm{N}_{2}$ fixation in mycorrhizal and nodulated fababeans (Vicia faba L.). Soil Biol. Biochem. 14: 407-412.

Marschner, H. and B. Dell. 1994. Nutrient uptake in mycorrhizal symbiosis. Plant Soil 159: 89-102.

Masri, B. M. 1997. Mycorrhizal inoculation for growth enhancement and improvement of the water relations in mangosteen (Garcinia mangostana L.) seedlings. Ph.D. Thesis. Universiti Putra Malaysia. Serdang, Malaysia. 
Newman, E. L. and P. Reddell. 1987. The distribution of mycorrhizas among families of vascular plants. New Phytol. 106: 745-751.

Owusu-Bennoah, E. and A. Wild. 1980. Effects of vesicular-arbuscular mycorrhiza on the size of the labile pool of soil phosphate. Plant Soil. 54: 233-242.

Read, D. J., D. H. Lewis, A. H. Fitter and I. J. Alexander. 1992. Mycorrhizas in Ecosystems. CAB International. Oxford.

Richardson, D. M., N. Allsopp, C. M. D. Antonio, S. J. Milton and M. Rejmanek. 2000. Plant invesions - the role of mutualisms. Biol. Rev. Cambridge Phyl. Soc. 75: 65-93.

Satter, M. A. 2000. The arbuscular mycorrhiza and phosphate rock in rehabilitation of tin tailings with Acacia mangium and peanut agroforestry system. Ph.D Thesis. Faculty of Agric., Universiti Putra Malaysia, Serdang, Malaysia. Pp. 1-255.

Satter, M. A. and D. Khanam. 2006. Effect of different sources of arbuscular mycorrhiza on the performance of chilli seedlings. Bangladesh J. Microbiol. 23(2): 98-101.

Son, C. L. and S. E. Smith. 1988. Mycorrhizal growth responses: interaction between photon irradiance and phosphorus nutrition. New Phytol. 108: 305-314.

Sramek, F., M. Dubsky and M. Vosatka. 2000. Effect of arbuscular mycorrhizal fungi and Trichoderma harzianum on three species of balcony plants. Rostlinna Vyroba. 146: $127-131$.

Syvertsen, J. P. and J. H. Graham. 1999. Phosphorus supply and arbuscular mycorrhizas increase growth and net gas exchange response in two Citrus spp. grown at elevated $\mathrm{CO}_{2}$. Plant Soil 208: 209-219.

Trappe, J. M. 1987. Phylogenetic and ecological aspects of mycotrophy in the angiosperms from an evolutionary standpoint. In: G.R. Safir (ed.) Ecophysiology of VA Mycorrhizal Plants. CRC Press. Boca Raton. Pp. 5-25. 